"Influence of profitability on responsibility accounting disclosure - Empirical study of Vietnamese listed commercial banks"

\begin{tabular}{|c|c|}
\hline AUTHORS & Tran Quoc Thinh (iD) \\
\hline ARTICLE INFO & $\begin{array}{l}\text { Tran Quoc Thinh (2021). Influence of profitability on responsibility accounting } \\
\text { disclosure - Empirical study of Vietnamese listed commercial banks. Banks and } \\
\text { Bank Systems, 16(2), 119-126. doi:10.21511/bbs.16(2).2021.11 }\end{array}$ \\
\hline DOI & http://dx.doi.org/10.21511/bbs.16(2).2021.11 \\
\hline RELEASED ON & Wednesday, 02 June 2021 \\
\hline RECEIVED ON & Monday, 14 September 2020 \\
\hline \multirow[t]{2}{*}{ ACCEPTED ON } & Friday, 28 May 2021 \\
\hline & $(\boldsymbol{c c}) \mathbf{E Y}$ \\
\hline LICENSE & $\begin{array}{l}\text { This work is licensed under a Creative Commons Attribution } 4.0 \text { International } \\
\text { License }\end{array}$ \\
\hline JOURNAL & "Banks and Bank Systems" \\
\hline ISSN PRINT & $1816-7403$ \\
\hline ISSN ONLINE & $1991-7074$ \\
\hline PUBLISHER & LLC "Consulting Publishing Company "Business Perspectives" \\
\hline FOUNDER & LLC "Consulting Publishing Company "Business Perspectives" \\
\hline & 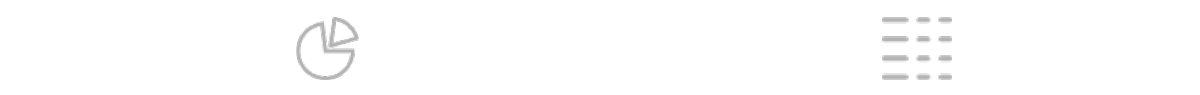 \\
\hline NUMBER OF REFERENCES & NUMBER OF FIGURES \\
\hline 31 & 0 \\
\hline
\end{tabular}

(C) The author(s) 2021. This publication is an open access article. 


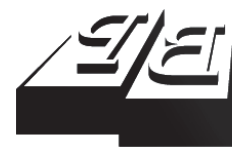

BUSINESS PERSPECTIVES

(O)

LLC "CPC "Business Perspectives"

Hryhorii Skovoroda lane, 10, Sumy, 40022, Ukraine

www.businessperspectives.org

Received on: $14^{\text {th }}$ of September, 2020

Accepted on: $28^{\text {th }}$ of May, 2021

Published on: $2^{\text {nd }}$ of June, 2021

๑ Tran Quoc Thinh, 2021

Tran Quoc Thinh, Associate Professor Ph.D., Lecturer, Faculty of Accounting and Auditing, Industrial University of Ho Chi Minh City, Vietnam.

\title{
INFLUENCE OF PROFITABILITY ON RESPONSIBILITY ACCOUNTING DISCLOSURE - EMPIRICAL STUDY OF VIETNAMESE LISTED COMMERCIAL BANKS
}

\begin{abstract}
Corporate social responsibility is the development trend in globalization. Businesses need to be accountable to shareholders. An organization should handle the relationship between community, economic, and social factors. The disclosure of responsibility accounting information by businesses has important implications for information users as well as stakeholders. The paper is intended to verify the influence of profitability on the disclosure of responsibility accounting of all listed commercial banks in Vietnam. The paper employs time series data for 2015-2019 and uses the ordinary least square method to test the model. Five independent variables related to profitability are examined. The results of the study show that ROA and ROE have a positive influence on responsibility accounting disclosure. Thereby, the state agencies of Vietnam need to promulgate regulations of responsibility accounting disclosure according to international standards and strictly control the disclosure of Vietnamese commercial banks to improve the quality of the information in the context of international integration.
\end{abstract}

\section{Keywords}

JEL Classification

\section{INTRODUCTION}

Corporate social responsibility (CSR) is a subject of special attention and is of greater importance in the context of economic globalization. It shows the role and responsibility of the business to the economy, community, and society. The business must reconcile the benefit of the related parties. It is an indispensable trend that shows a long-term and sustainable business strategy. Abeysinghe and Basnayake (2015) said that the interest of stakeholders has driven the increase in CSR of enterprises through annual reports. Information disclosure ensures transparency and appropriateness in environmental, social, humanitarian, and ethical issues. It is an action that shows the responsibility of the business to the community. Matuszak and Różańska (2017) recognized that enterprises need to have long-term business strategies and these strategies must ensure community benefits. The improvement of the living environment and social responsibility will create a reputation and enhance competitive value. Therefore, profitability always has a connection with responsibility accounting disclosure (ADISC). Gallardo-Vázquez et al. (2019) examined the need for ethical values of the business in demonstrating its responsibility to society and the community. ADISC is the image of the business shown to the outside, and stakeholders will check that. Therefore, the economic 
growth of a business must be in the context of the community. Sustainable finance is a combination of economic growth, economic, social, and environmental benefits. It shows that the business invests responsibly with a sustainable business strategy, the standard of social and environmental risk management. Therefore, ADISC is a message to all stakeholders (Kustono \& Nanggala, 2019). The role of the banking industry must ensure national financial stability and is also seen as the mainstay leading the economy. Therefore, the ADISC of banks needs to be included in annual reports. Under the pressure of economic growth, CSR needs to be maintained and promoted to ensure community and society. It creates spillovers in the economy to maintain sustainable development (Szegedi et al., 2020).

In the development process, Vietnam has been under great pressure to resolve the relationship between economic development and CSR. Many foreign companies invest in Vietnam in a number of heavy industries. While some legal regulations are not yet strict, the environment, community, and social issues have not been given adequate attention. This issue has been alarming recently through a number of cases of greenhouse gas emissions, direct hazardous waste emissions into the environment, labor policy, and employee welfare. Summarizing over the past 10 years, businesses violated the cases of law violations on the environment, natural resources, and food safety from 2006 to 2016 (Vietnamese Ministry of Public Security, 2016). It is a warning issue about CSR in Vietnam. Business managers are concerned about profitability and economic growth, but do not pay much attention to CSR (Ta \& Bui, 2018, Nguyen et al., 2020). Recently, in order to maintain CSR, Vietnam has revised the legal provisions on the Law on Environmental Protection related to environmental, community, and social issues (National Assembly of Vietnam, 2014). For listed businesses like listed commercial banks, Circular 155 regulated ADISC on the securities market (Vietnamese Ministry of Finance, 2015). In Vietnam, research on the ADISC of the banking sector is limited. According to experts from the Central bank of Vietnam, these are the subjects most likely to meet ADISC requirements. The article selects data in the annual reports of these banks for the most recent 5 years. It is the period when the newly revised legal regulations of the Law on environmental protection (2014) and Circular 155 regulate the presentation of ADISC in 2015.

\section{LITERATURE REVIEW}

Currently, there are many concepts related to CSR in different aspects. Bowen (1953) considered that CSR is a commitment to ethical issues to ensure the growth of enterprises on the basis of harmony with the economy, community, and society. Carroll $(1979,1991,1999)$ recognized that CSR is a core responsibility that businesses must commit to performing in the course of doing business. Commitments to fairness among stakeholders include economic, legal, ethical, and discretionary. Gray et al. (1996) examined ADISC to be the communication process for relevant interest groups in society. ADISC reflects the corporate image externally, and it will influence the value of the company. Most companies have ADISC but they must maintain and ensure community, as well as society, in the process of doing business. Heal (2005) argued that CSR is the participation of various actions to avoid conflicts of interest between parties. It shows that good ADISC will help reduce risks, improve relationships with regulators, cre- ate brand value, and improve human relationships. Starks (2009) said that ADISC is a commitment of an enterprise to create sustainable development for workers, local communities, and society in general. Han et al. (2016) believed that ADISC is a form of business that self-adjusts to ensure the ethical standards of the business. It represents a business strategy with long-term survival by building good and fair relationships with stakeholders.

The ADISC measurement varies due to characteristics and requirements between different sectors and countries. Global reporting initiatives (GRI) are measures based on social, economic, and environmental concerns. Triple bottom line (TBL) uses three main dimensions such as social, economic, and environmental (Bidari, 2016). However, this paper presents new empirical research about ADISC by Circular 155 for Vietnamese listed commercial banks.

For profitability, Fry (2005) believed that profitability is the result of a process related to the busi- 
ness activities of an enterprise. It is the difference between the results obtained and the cost to get that result. Weber (2009) considered that profitability is a benefit brought in the process of doing business and by the ability to create profits of the business. Profitability is determined by the change of assets, capital sources, and investment value. Depending on the field of business or industry, the previous studies have measured the factors of profitability that affect ADISC on the basis of ROA (Jizi et al., 2014; Bidari, 2016); either ROE (Mita et al., 2018; Kustono \& Nanggala, 2019) or a combination of ROA and ROE (Mallin et al., 2014; Jahid et al., 2020; Ridwan \& Mayapada, 2020) or multiple factors of ROA, ROE, and EPS (Akter et al., 2018; Szegedi et al., 2020); ROA, ROE, and NIM (Matuszak \& Różańska, 2017); ROA, ROE and NPM (Mukhibad et al., 2020). However, to have a more diverse view, differences compared to previous studies, the independent variables of this paper used in the model are more universal, including ROA, ROE, EPS, NIM, and NPM. According to experts from the Central bank of Vietnam, they are the significant factors in Vietnamese conditions, and the combination of these variables has not been performed in previous studies.

The fundamental theory that was widely used in previous studies is legitimacy and stakeholder theory to examine the factors of profitability that influence ADISC (Mallin et al., 2014; Bidari, 2016; Mita et al., 2018; Kustono \& Nanggala, 2019; Jahid et al., 2020; Ridwan \& Mayapada, 2020). The legitimacy theory states that an enterprise should conduct activities to harmonize with the value systems and ethical standards (Dowling \& Pfeffer, 1975). This theory considers that an enterprise has a commitment to social responsibility with the community and the environment in which it operates. The legitimacy theory explains the behavior of organizations to ADISC (Bidari, 2016). Therefore, businesses implement ADISC to legalize their actions and to get social approval. An organization also needs to keep in mind ethical and cultural values to comply with social norms to ensure legitimacy (Jahid et al., 2020). Moreover, the stakeholder theory was formulated by Freeman in 1984. This theory concerns the connection between an enterprise and stakeholders, whereby stakeholders influence the performance of a business to meet their expectations (Freeman, 1984).
The theory considers the contractual relationships between all related parties. Stakeholders include employees, creditors, suppliers, customers, and local communities (Mallin et al., 2014). All stakeholders contribute to an enterprise so the enterprise should pay attention to the related interests (Ridwan \& Mayapada, 2020).

Several studies have checked the influence of profitability on ADISC. The perceived results differ as positive, negative, or neutral due to geographic scope, time, and subjects of study. Typically, Mallin et al. (2014) examined that profitability affected ADISC of 90 Islamic banks across 13 countries from 2010 to 2011. The article applied the OSL regression. The results show that there are two variables positively affecting ADISC such as ROA and ROE. Mita et al. (2018) investigated the profitability impact on ADISC of commercial banks in Singapore, Indonesia, Malaysia, the Philippines, and Thailand in 2014. The article used OLS to check the multivariate regression. The results indicate that ROE has a positive effect on ADISC in Thailand and Indonesia but it is not significant for Malaysia, the Philippines, and Singapore.

In addition, a number of studies consider the factors of profitability that affect ADISC. Jizi et al. (2014) checked the factors affecting ADISC of US commercial banks from 2009 to 2011. The ordinary least square is used to examine the model. The results find that ROA does not have a positive effect on ADISC. Bidari (2016) considered factors affecting ADISC in banks of Nepal. The article used a sample of 82 observations in 2014. Multiple regression method was also used. The results show that ROA has a positive effect on ADISC. Kustono and Nanggala (2019) studied the factors that influence the ADISC of 13 Indonesian banks from 2015 to 2017. Panel data is examined by regression. The results demonstrate that ROE does not have a positive impact on ADISC. Ridwan and Mayapada (2020) investigated the factors affecting the ADISC of ten Indonesian banks. The article uses annual reports of these banks from 2011 to 2018 and applies OLS. The results show that ROA and ROE do not affect ADISC. Jahid et al. (2020) checked factors affecting ADISC in Bangladesh. The article applies OLS to test the model. The data is collected from 30 publicly-listed banks from 2013 to 2018. The results show that ROA has an 
Table 1. Defining and measuring independence variables

Source: Author's summary.

\begin{tabular}{|c|c|c|c|}
\hline Symbol & Variable name & Measurement & Previous studies related \\
\hline ROA & Return on assets & Net income/Total assets.100\% & $\begin{array}{l}\text { Mallin et al. (2014), Jizi et al. (2014), Bidari (2016), Matuszak and } \\
\text { Różańska (2017), Akter et al. (2018), Jahid et al. (2020), Ridwan and } \\
\text { Mayapada (2020), Mukhibad et al. (2020) }\end{array}$ \\
\hline ROE & Return on equity & Net income/Total equity·100\% & $\begin{array}{l}\text { Mallin et al. (2014), Matuszak and Różańska (2017), Mita et al. } \\
\text { (2018), Akter et al. (2018), Kustono and Nanggala (2019), Jahid et } \\
\text { al. (2020), Ridwan and Mayapada (2020), Mukhibad et al. (2020) }\end{array}$ \\
\hline EPS & Earning per share & $\begin{array}{l}\text { Natural logarithm of (Net income } \\
\text { - preferred dividends/Average } \\
\text { outstanding common shares) }\end{array}$ & Akter et al. (2018) \\
\hline NPM & Net profit margin & Net profit/Revenue-100\% & Mukhibad et al. (2020) \\
\hline NIM & Net interest margin & $\begin{array}{c}\text { Net interest income/Total } \\
\text { assets.100\% }\end{array}$ & Matuszak and Różańska (2017) \\
\hline
\end{tabular}

effect in the same direction, while ROE has no effect on ADISC.

In Vietnam, a developing country in Asia, research on ADISC is limited. Nguyen (2018) considered the relationship between profitability and ADISC of credit institutions in Vietnam over the period from 2011 to 2016. The article used OLS. However, ADISC was used as the independent variable. Results show that ROA has opposite effects on ADISC. Previous studies have explored the impact of factors on ADISC but these studies chose enterprises. So, Ta and Bui (2018) studied the factors affecting ADISC of 43 companies listed in Vietnam from 2006 to 2016. Nguyen et al. (2020) examined the factors affecting ADISC of 120 Vietnamese listed companies in 2020. Due to limited studies on ADISC in Vietnam, particularly in the banking sector, this study chooses the subject of listed commercial banks in Vietnam. It helps to more specifically identify ADISC of the banking sector in Vietnam in order to have policies that will help improve ADISC in Vietnam in line with the trend of global integration.

\section{METHODOLOGY}

Vietnam has 18 commercial banks listed on the stock market. However, some banks do not have annual reports for many years, so the information is not used for the sample. Thus, the data sample includes 86 observations from 2015 to 2019. The paper uses OLS and Eviews 10 to check the model.

According to experts from the Central bank of Vietnam, combining characteristics and econom- ic conditions in Vietnam, the paper considers the influence of profitability on ADISC of listed commercial banks. The regression model is presented as follows:

$$
\begin{aligned}
& A D I S C=\beta_{0}+\beta_{1} \cdot R O A+\beta_{2} \cdot R O E+ \\
& +\beta_{3} \cdot E P S+\beta_{4} \cdot N P M+\beta_{5} \cdot N I M+\varepsilon
\end{aligned}
$$

ADISC is measured as follows:

$$
I_{i j, t}=\frac{\sum_{i=1}^{n_{j}} d_{i j}}{n_{j}},
$$

where $I_{i, j}-A D I S C$ of listed commercial banks, $0 \leq$ $I_{j} \leq 1 ; d_{i j}$ is 1 if the item $i$ is recorded, 0 if the item $i$ is not recorded; $n_{j}$ is the number of items of ADISC; $t$ - figures from 2015 to 2019.

\section{RESEARCH RESULTS}

According to the results of Table 2, the ADISC of the listed commercial banks from 2015 to 2019 is good, with an average rate of $81.30 \%$, accordingly, the highest rate is $95.40 \%$ and the lowest is $68.10 \%$. It shows that the listed commercial banks may also be under pressure from shareholders and related parties, so it has contributed to increasing ADISC. The indicators related to profitability are also quite high: the average ROA, ROE, NPM, and NIM are $2.01 \%$, $25.89 \%, 52.54 \%$, and $5.58 \%$, respectively, and EPS is 4.31 . The standard deviation of all variables is negligible. 
Table 2. Descriptive statistics

Source: Eviews 10 data.

\begin{tabular}{|c|c|c|c|c|c|c|}
\hline Variables & ADISC & ROA & ROE & EPS & NPM & NIM \\
\hline Mean & 0.813 & 2.014 & 25.894 & 4.311 & 52.542 & 5.583 \\
\hline Maximum & 0.954 & 3.504 & 41.107 & 5.841 & 71.902 & 6.712 \\
\hline Minimum & 0.681 & 1.028 & 11.214 & 3.591 & 36.054 & 2.258 \\
\hline Standard deviation & 0.145 & 0.012 & 0.458 & 0.024 & 0.067 & 0.036 \\
\hline Number of observations & 86 & 86 & 86 & 86 & 86 & 86 \\
\hline
\end{tabular}

Table 3 shows that the correlation coefficients of variables are closely correlated. All correlation coefficients are between 0.321 and 0.562 . It shows that significant data guarantee reliability. Moreover, the coefficients of variables are low and less than 0.8 , therefore, the model result is not multicollinear (Hair et al., 2006).

According to Table 4, R squared adjustment is 0.6481, and this means that the model results explained $64.81 \%$, equivalent to explaining $64.1 \%$ of the impact of the independent variables. The regression results indicate that the probability is 0.00 (less than 0.05). The results show that ROA and ROE have a positive impact on ADISC. Accordingly, the specific model results are as follows:

$$
\begin{aligned}
& A D I S C=0.504+0.418 \cdot R O A+ \\
& +0.692 \cdot R O E .
\end{aligned}
$$

In addition, this paper uses the Wu-Hausman test to check endogenous variables, according to which the following hypothesis is proposed:

H0: The model has no the diagnostic phenomenon.

H1: The model has the diagnostic phenomenon.

Table 5 shows that the p-value is 0.000 and less than 0.05 , so $\mathrm{H} 0$ is accepted and $\mathrm{H} 1$ is rejected. Therefore, the model has no diagnostic phenomenon.

Table 3. Correlation coefficients

\begin{tabular}{|c|c|c|c|c|c|c|}
\hline Variables & ADISC & ROA & ROE & EPS & NPM & NIM \\
\hline ADISC & 1.000 & - & - & - & - & - \\
\hline $\mathrm{ROA}$ & 0.402 & 1.000 & - & - & - & - \\
\hline ROE & 0.562 & 0.321 & 1.000 & - & - & - \\
\hline EPS & 0.476 & 0.392 & 0.521 & 1.000 & - & - \\
\hline NPM & 0.387 & 0.403 & 0.436 & 0.481 & 1.000 & - \\
\hline NIM & 0.429 & 0.437 & 0.418 & 0.473 & 0.421 & 1.000 \\
\hline
\end{tabular}

Source: Eviews 10 data.

Table 4. Regression result

\begin{tabular}{|c|c|c|}
\hline \multirow{2}{*}{ Variables } & \multicolumn{2}{|c|}{ ADISC } \\
\hline & $\alpha$ & p-value \\
\hline (Constant) & 0.504 & 0.000 \\
\hline $\mathrm{ROA}$ & 0.418 & 0.000 \\
\hline $\mathrm{ROE}$ & 0.692 & 0.000 \\
\hline EPS & 0.346 & 0.593 \\
\hline NPM & 0.527 & 0.702 \\
\hline NIM & 0.482 & 0.841 \\
\hline Observations & \multicolumn{2}{|c|}{86} \\
\hline$R$ squared & \multicolumn{2}{|c|}{0.7625} \\
\hline R squared adjustment & \multicolumn{2}{|c|}{0.6481} \\
\hline F-statistics & \multicolumn{2}{|c|}{12.419} \\
\hline Probability (F-statistics) & \multicolumn{2}{|c|}{0.0000} \\
\hline
\end{tabular}

Source: Eviews 10 data.

Table 5. Diagnostic test

Source: Eviews 10 data

\begin{tabular}{l|c|c|c|c|c}
\hline \multicolumn{1}{c|}{ Diagnostic test } & df1 & df2 & statistic & p-value \\
\hline Wu-Hausman & 1 & 81 & $1.306 \mathrm{e}+08$ & 0.000 \\
\hline
\end{tabular}




\section{DISCUSSION AND POLICY RECOMMENDATIONS}

The research results are consistent with Mallin et al. (2014), Bidari (2016), and Jahid et al. (2020). Regarding previous studies of Vietnam, the results of this study are not similar due to the difference in study subjects and time frame.

Vietnamese listed commercial banks have been quite fully compliant with ADISC over the past time. The average rate of CSRS is $81.30 \%$. Moreover, considering each year, the average rate of ADISC also increases over the years. It is a good rate and a positive sign. Vietnamese listed commercial banks are among Vietnam's key industries and received high attention from stakeholders. Therefore, compliance with ADISC is encouraging. However, some of the listed commercial banks have yet to be fully announced with a minimum ADISC of $68.10 \%$.

There are two factors that influence ADISC in Vietnamese listed commercial banks - ROA and ROE. ROE has a higher impact level than ROA. This shows that listed commercial banks with high economic efficiency will tend to increase ADISC. Usually, listed commercial banks are highly profitable, so they want to promote more images and create brand value and reputation for banks.
Through that, listed commercial banks would also like to send messages to stakeholders about their CSR. This contributes to the confidence of stakeholders. Furthermore, through the ADISC, listed commercial banks also demonstrate compliance with the laws that represent a contract of the commitment of responsibility between them and related parties.

On the basis of the survey results, the Vietnamese government should urgently revise CSR regulations to comply with international standards. Moreover, the Central bank of Vietnam needs to raise awareness of bank managers so that they comply with the regulations. The Central bank should regularly monitor the ADISC of listed commercial banks. Further, bank managers need to show their responsibility to the community and society. They need to have a long-term development strategy based on the harmony between economic growth, community, and society. The State Securities Commission of Vietnam needs to regularly inspect the ADISC of listed commercial banks. Some of the additional investigative sanctions required for listed commercial banks do not provide complete ADISC. The State Securities Commission of Vietnam may even consider delisting listed commercial banks that have repeatedly violated ADISC.

\section{CONCLUSION}

In the context of global economic integration, CSR is concerned with economic growth. It is not a matter of a country or a region, it is a global problem. The research results show that profitability factors, including ROA and ROE, have a positive influence on ADISC of Vietnamese listed commercial banks, of which ROE has a higher influence than ROA. On that basis, Vietnamese government authorities should standardize CSR regulations in accordance with international criteria, as well as strengthen ADISC monitoring of listed commercial banks. Furthermore, government authorities can impose severe sanctions and even delisting if Vietnamese listed commercial banks disclose incomplete and non-transparent ADISC information. This demonstrates fairness between stakeholders to ensure harmony of economic, social, and community relationships and increase the sustainability of economic growth.

\section{AUTHOR CONTRIBUTIONS}

Conceptualization: Tran Quoc Thinh.

Data curation: Tran Quoc Thinh.

Formal analysis: Tran Quoc Thinh.

Funding acquisition: Tran Quoc Thinh.

Investigation: Tran Quoc Thinh.

Methodology: Tran Quoc Thinh. 
Project administration: Tran Quoc Thinh.

Resources: Tran Quoc Thinh.

Software: Tran Quoc Thinh.

Supervision: Tran Quoc Thinh.

Validation: Tran Quoc Thinh.

Visualization: Tran Quoc Thinh.

Writing - original draft: Tran Quoc Thinh.

Writing - reviewing \& editing: Tran Quoc Thinh.

\section{REFERENCES}

1. Abeysinghe, A. M. I. P., \& Basnayake, W. B. M. P. (2015). Relationship between corporate social responsibility disclosure and financial performance in Sri Lankan domestic banking industry. Conference on Business \& Information, vol. (2015), pp. 111-128. Retrieved from http://repository.kln.ac.lk/handle/123456789/10554

2. Akter, N., Siddik, A. B \& Mondal, S. A. (2018). Corporate Social Responsibility Disclosure Practices and Banks Financial Performance: A Study on Listed Private Commercial Banks in Bangladesh. Journal of business and Technology, 13(1), 1-19. Retrieved from https://islamicmarkets.com/publications/ corporate-social-responsibilitydisclosure-practices-and-banksfinancial-performance-a

3. Bidari, G. (2016). Factors affecting CSR disclosure in Nepalese banks: a global reporting initiative perspective (Master's Thesis). Edith Cowan University. Retrieved from https://ro.ecu.edu.au/theses/1803

4. Bowen, H. R. (1953). Social Responsibilities of the Businessman. New York City, NY: Harper \& Brothers. Retrieved from https://openlibrary.org/books/ OL6132911M/Social_Responsibilities_of_the_Businessman

5. Carroll, A. (1979). A threedimensional conceptual model of corporate performance. The Academy of Management Review, 4(4), 497-505. http://dx.doi. org/10.2307/257850

6. Carroll, A. (1991). The pyramid of corporate social responsibility: Toward the moral management of organizational stakeholders. Business Horizons, 34(4), 39-48. http://dx.doi.org/10.1016/00076813(91)90005-g

7. Carroll, A. (1999). Corporate Social Responsibility: Evolution of a Definitional Construct. Business \& Society, 38(3), 268-295. http://dx.doi. org/10.1177/000765039903800303

8. Dowling, J., \& Pfeffer, J. (1975). Organizational legitimacy: societal values and organizational behavior. Pacific Sociological Review, 18(1), 122-136. https://doi. org/10.2307/1388226

9. Freeman, R. E. (1984). Strategic management: A stakeholder approach. Boston: Pitman Publisher.

10. Fry, M. (2005). Adam Smith' Legacy - His place in development of modern economics. London: Routledge Press.

11. Gallardo-Vázquez, D., BarrosoMéndez, M., Pajuelo-Moreno, M. L., \& Sánchez-Meca, J. (2019). Corporate Social Responsibility Disclosure and Performance: A Meta-Analytic Approach. Sustainability, 11(4), 1-33. http:// doi.org/10.3390/su11041115

12. Gray, R., Owen, D., \& Adams, C., (Eds.). (1996). Accounting and Accountability: Changes and Challenges in Corporate Social and Environmental Reporting. London: Prentice-Hall.

13. Han, J. J., Kim, H. J., \& Yu, J. (2016). Empirical study on relationship between corporate social responsibility and financial performance in Korea. Asian Journal of Sustainability and Social
Responsibility, 1, 61-76. http://doi. org/10.1186/s41180-016-0002-3

14. Heal, G. (2005). Corporate social responsibility: An economic and financial framework. The Geneva papers on risk and insurance Issues and practice, 30(3), 387409. Retrieved from https://link. springer.com/article/10.1057/ palgrave.gpp. 2510037

15. Jahid, A., Rashid, H. U., Hossain, S. Z., Haryono, S., \& Jatmiko, B. (2020). Impact of Corporate Governance Mechanisms on Corporate Social Responsibility Disclosure of Publicly-Listed Banks in Bangladesh. Journal of Asian Finance, Economics and Business, 7(6), 61-71. http://doi. org/10.13106/jafeb.2020.vol7. no6.061

16. Jizi, M., Salama, A., Dixon, R., \& Stratling, R. (2014). Corporate governance and corporate social responsibility disclosure: evidence from the US banking sector. Journal of Business Ethics, 125(4), 601-615. http://dx.doi. org/10.1007/s10551-013-1929-2

17. Kustono, A. S., \& Nanggala, A. Y. A. (2019). Corporate Social Responsibility disclosure of Sharia Banks in Indonesia. International Conference on Economics, Education, Business and Accounting, 2019, 760-777. http:// doi.org/10.18502/kss.v3i11.4049

18. Mallin, C., Farag, H., \& OwYong, K. (2014). Corporate social responsibility and financial performance in Islamic banks. Journal of Economic Behavior \& Organization, 103, 21-38. http://dx.doi.org/10.1016/j. jebo.2014.03.001 
19. Matuszak, L., \& Różańska, E. (2017). An examination of the relationship between CSR disclosure and financial performance: The case of Polish banks. Accounting and Management Information Systems, 16(4), 522-533. http://dx.doi. org/10.24818/jamis.2017.04005

20. Mita, A. F., Silalahi, H. F., \& Halimatussadiah, A. (2018). Corporate social responsibility disclosure and banks' financial performance in five ASEAN countries. Journal of Economics, Business, and Accountancy, 21(2), 159-167. Retrieved from https:// journal.perbanas.ac.id/index.php/ jebav/article/view/1437

21. Mukhibad, H., Muthmainah, M., \& Andraeny, D. (2020). The Role of Corporate Social Responsibility Disclosure in Improving Financial Performance (Case study in Indonesian Islamic Bank). Journal of Islamic Economics, 4(2), 162173. http://doi.org/10.26740/aluqud.v4n2.p162-173

22. National Assembly of Vietnam. (2014). Law on environmental protection No. 55/2014/QH13. Retrieved from https://vanbanphapluat.co/law-no-55-2014-qh13on-environmental-protection

23. Nguyen, B. N. (2018). The Effect of Corporate Social Responsibility disclosure on Financial

Performance: Evidence from

Credit Institutions in Vietnam.

Asian Social Science, 14(4), 109-

122. https://doi.org/10.5539/ass.

v14n4p109

24. Nguyen, T. L. H., Nguyen, T. T. H., Nguyen, T. T. H., Le, T. H. A., \& Nguyen, V. C. (2020). The Determinants of Environmental Information disclosure in Vietnam Listed Companies. The Journal of Asian Finance, Economics and Business, 7(2), 21-31. https://doi. org/10.13106/jafeb.2020.vol7. no2.21

25. Ridwan, R., \& Mayapada, A. G. (2020). Does sharia governance influence corporate social responsibility disclosure in Indonesia Islamic banks? Journal of Sustainable Finance \& Investment, 4, 1-20. https://doi.org /10.1080/20430795.2020.1749819

26. Starks, L. T. (2009). EFA Keynote Speech: Corporate Governance and Corporate Social Responsibility: What Do Investors Care about? What Should Investors Care about? The Financial Review, 44(4), 461-468. Retrieved from https://onlinelibrary.wiley.com/doi/abs/10.1111/ j.1540-6288.2009.00225.x

27. Szegedi, K., Khan, Y., \& Lentner, C. (2020). Corporate Social
Responsibility and Financial Performance: Evidence from Pakistani Listed Banks. Sustainability, 12(10), 1-19. https://doi.org/10.3390/ su12104080

28. Ta, T. T. H., \& Bui, T. N. (2018). Effect of Corporate Social Responsibility disclosure on Financial Performance. Asian Journal of Finance \& Accounting, 10(1), 40-58. https://doi. org/10.5296/ajfa.v10i1.12592

29. Vietnamese Ministry of Finance. (2015). Circular 155 on disclosure of information on the securities market. Vietnamese news. Retrieved from https:// vbpq.mof.gov.vn/Detail?content Type $=$ LegalDocument\&id $=1907$ $0 \& \mathrm{tab}=99$

30. Vietnamese Ministry of Public Security. (2016). Disclosure covering over 100,000 cases of law violation on environment, natural resources and food safety, 2006-2016 period. Vietnamese news. Retrieved from http://congan.travinh.gov.vn/ ch10/366-2006-2016-Kham-phatren-100000-vu-vi-pham-phapluat-ve-moi-truong-tai-nguyenan-toan-thuc-pham.html

31. Weber, M. (2009). General economic history. New York: Dover Publication. 